
\title{
ОТДЕЛЬНЫЙ КАВКАЗСКИЙ КОРПУС КАК ВОЕННАЯ КОРПОРАЦИЯ (ПО МАТЕРИАЛАМ ПОЛКОВЫХ ИСТОРИЙ)
}

\section{SEPARATE CAUCASIAN CORPS AS A MILITARY CORPORATION (BASED ON THE MATERIALS OF REGIMENTAL HISTORIES)}

\section{P. Chernov}

Summary: The regiments that fought for decades in the Caucasus with the Turks, Persians and mountaineers, operating in the specific conditions of this region, formed a special community that had a number of corporate features (traditions, combat techniques, ideas about the norms of military law, their own list of heroes and "places of memory"). These signs of the corporation appeared in the regimental stories, which became a prominent phenomenon in the military subculture of the last third of the XIX - early XX centuries.

Since the beginning of the XIX century, the newly formed Separate Caucasian Corps, which became the "unofficial" Caucasian Guard, successfully defended the interests of the Russian Empire on the southern borders of the country. The natural-climatic and socio-cultural factors, the tactics of warfare, the heterogeneity of the personnel of the regiments, allowed us to form special traditions and our own pantheon of heroes of the Caucasian Army. But the Eurocentric nature of the imperial policy did not allow us to sufficiently assess the merits of the Caucasian regiments. Breaking the established prejudices, the regimental chroniclers tried to convey to their colleagues and society the undeservedly forgotten feat of arms of the soldiers of the Caucasian Corps.

Since the last third of the XIX century, active work has been carried out on the publication of regimental histories of the Caucasian Army. Regimental legends were supplemented with stories about the heroic exploits of fellow soldiers, arguments about the actions of generals and the local population, the betrayal of individual recruits from among the exiled Poles, claims to a special connection with famous generals and monarchical persons. The desire to glorify his unit remained unchanged, singling it out from the general mass of the Caucasian regiments.

Keywords: the Russian army, the Caucasian corps, the conquest of the Caucasus, regimental stories, corporate history, heroes of the Caucasian war.

В течение XIX столетия в ходе завоевания Закавказья и затяжной борьбы с горцами Северного Кавказа сформировалось воинское соединение, обособленное от остальной армии России, получившее название Отдельный Кавказский Корпус (до 1820 г. - Грузинский корпус, с 1857 г. - Кавказская армия).

Эта военная группировка претендовала на признание ее особых заслуг в строительстве империи («поко-
Чернов Павел Вячеславович

соискатель, Санкт-Петербургский институт истории Российской академии наук, г. Санкт-Петербург pulsar.pvl@mail.ru

Аннотация: Полки, десятилетиями воевавшие на Кавказе с турками, персами и горцами, действовавшие в специфических условиях этого региона, сформировали особую общность, имевшую ряд корпоративных черт (традиции, боевые приемы, представления о нормах военного права, свой список героев и «мест памяти»). Эти признаки корпорации проявились в полковых историях, которые стали заметным явлением в военной субкультуре последней трети XIX - начала XX Вв.

С началом XIX столетия вновь сформированный Отдельный Кавказский Корпус, ставший «неофициальной» Кавказской гвардией, успешно отстаивал интересы Российской империи на южных рубежах страны. Природно-климатический и социокультурный факторы, тактика ведения боевых действий, неоднородность личного состава полков, позволили сформировать особые традиции и свой пантеон героев Кавказской армии. Но европоцентристский характер имперской политики не позволял в достаточной мере оценить заслуги Кавказских полков. Ломая устоявшиеся предубеждения, полковые летописцы, старались донести до сослуживцев и общества незаслуженно забытый ратный подвиг воинов Кавказского Корпуса.

Начиная с последней трети XIX века, развернулась активная работа по изданию полковых историй Кавказской армии. Полковые сказания пополнялись историями о героических подвигах однополчан, рассуждениями о действиях полководцев и местного населения, предательстве отдельных новобранцев из числа ссыльных поляков, притязаниями на особую связь со знаменитыми полководцами и монархическими особами. Неизменным оставалось желание, прославить свое подразделение, выделив его из общей массы Кавказских полков.

Ключевые слова: Российская армия, кавказский корпус, завоевание Кавказа, полковые истории, корпоративная история, герои кавказской войны.

рение Кавказа»), и на свой особый статус. Пехотные полки, воевавшие еще под командованием А.П. Ермолова (Апшеронский, Грузинский, Кабардинский, Кавказский, Куринский, Мингрельский, Навагинский, Тенгинский, Тифлисский, Ширванский, Эриванский) и кавалерийские полки (Тверской драгунский и Нижегородский драгунский), сформировали неофициальную местную «гвардию» с такой же неофициальной внутренней иерархией [1, с.9-13]. 
На складывание корпоративного сознания войск отдельного Кавказского корпуса очень сильное влияние оказали четыре фактора. Первый из них - обособленность и удаленность Кавказского театра военных действий от Европы, устойчивое представление о нем как об «Азии». Второй - практическая непрерывность боев разного масштаба и характера, а также особый характер боевых операций, особое отношение к противнику, особые «законы войны», практически не изменявшиеся на протяжении полутора столетий. Третий фактор - естественное в условиях такой обособленности Кавказского театра боевых действий складывание особого списка героев, а также «памятных мест» в виде перечня главных сражений. Наконец, четвертый фактор - сравнительно стабильный состав Отдельного кавказского корпуса, что в значительной степени способствовало формированию представления о нем, как об отдельной общности.

Результатом побед войск Кавказского корпуса над Турцией и Персией (все кампании в Закавказье были успешными) в 1804-1813, 1826-1829, 1853-1856 и 18771878 гг. стало присоединение огромных территорий. Еще в XVIII веке имели место многочисленные столкновения русских войск с горцами Северного Кавказа, но по своим масштабам они значительно уступали тем, которые начались в следующем столетии. Стратегический перелом в Кавказской войне наметился в 1850-е гг., а в 1859 г. после взятия аула Гуниб и пленения имама Шамиля масштабные боевые действия в Чечне и Дагестане прекратились. В 1860-1864 гг. было подавлено организованное сопротивление горцев Западного Кавказа. Несмотря на официальное окончание войны, напряженность сохранялась, происходили различные вооруженные выступления, требовавшие применения войск для их подавления. Наиболее значительным стало восстание в Чечне и Дагестане в 1877-1878 гг. [2, с.78-79].

Для полков кавказской армии фокусировка внимания на их боевых заслугах в боях против горцев, персов и турок была своеобразной компенсацией за европоцентричность отечественного военно-исторического нарратива. Российская империя смотрела на запад, и презентовала Европе свою воинскую доблесть, прежде всего в знаковых победах с французами, шведами и турками. Легендарный кавказский генерал П.С. Котляревский, сыгравший важную роль в войне с Персией 1804-1813 гг., сетовал в 1846 г. на забвение героев сражений на Кавказе, что выглядело, по его мнению, особо несправедливо на фоне внимания к участникам войны с Наполеоном [3; 4, с.186-187]. Генерал-майор С.О. Кишмишев писал в одной из лучших монографий по истории Русско-Турецкой войны 1877-1878 гг.: «Четыре раза в XIX столетии Азиатская Турция становилась для нас театром военных действий, и каждый раз, когда нам там приходилось иметь дело, внимание наше было отвлечено другим театром войны, событиями на Дунае, на Балканах, в Крыму, вообще ходом дел в Европе решалась участь наших войн с Турцией. То же, что совершалось в Азии, служило только придатком к летописям нашей военной славы. [...] Война в Азиатской Турции в представления русского общества рисовалась чем-то отдаленным и малозначащим - точно не наши сыновья и не наши братья совершали там чудеса геройства и проливали кровь свою, и каждый раз, как громы ее умолкали, самая память о ней как бы исчезала бесследно...» [5, с.V].

Если войскам, дислоцированным в Европейской части Российской империи, приходилось воевать со значительными перерывами, то части, оказавшиеся на Кавказе, находились в обстановке постоянной военной угрозы. В первом случае солдатам и офицерам приходилось иметь дело с разными противниками (шведы, немцы, поляки, французы, турки, англичане). Во втором - с неприятелем, очень заметно отличавшимся от вышеперечисленных врагов, и при этом имевшим между собой множество сходных черт. Важным был и природно-климатический фактор. В Финляндии, Польше, Германии, и даже в Молдавии и Болгарии, где неоднократно приходилось действовать русским полкам, ландшафт, погода и образ жизни населения не отличался настолько, как это было в случаях с Дагестаном, Азербайджаном, Грузией и Чечней. Войска, десятилетиями воевавшие на Кавказе, оказывались буквально во всех отношениях в ином мире, чем их товарищи по оружию, которые воевали на западном направлении.

Важным отличием «кавказского» типа боевых действий от типа «европейского» была перемена местами таких символичных определений как авангард и арьергард. Поскольку достижение победы обеспечивалось, прежде всего, решительным наступлением, именно передовой части армии (авангарду), проламывающему неприятельскую оборону подчас ценой больших потерь, доставались наибольшие лавры. На западных театрах военных действий, группировка, прикрывающая тыл главных сил (арьергард), добивалась признания товарищей по оружию только в особых условиях, связанных с отступлением, которые обязательно при этом должны были быть героизированы [6, с.42]. На Кавказе наоборот, отход требовал больше ратного мастерства и оплачивался большими потерями, чем наступление. Поэтому Кабардинский полк, один из лучших на Кавказе, называли «арьергардным», что являлось признанием его навыков выполнять самую трудную ратную работу - прикрывать отступающую колонну [7, с.80].

Длительный процесс завоевания Кавказа сопровождался складыванием списка местных топонимов, которые стали играть роль символов боевой славы войск, там воевавших. Это были названия крепостей и мест, где разворачивались наиболее значимые сражения - Ахалцых, Дарго, Ахульго, Эривань, Карс, Баязет, Валерик, Башкадыкляр и др. 
На Кавказе сложился свой героический пантеон - ряд образов военачальников, а также офицеров и солдат, совершивших подвиги, описание которых стало обязательной частью почти всех историй полков, составлявших Отдельный Кавказский корпус. Из всех полководцев «всероссийского значения» на Кавказе были только А.В. Суворов и П.И. Багратион. Первый к тому же в столкновениях с горцами не участвовал, войска под его началом громили ногайское ополчение в степных районах за Кубанью. Знаменитый герой Отечественной войны 1812 года на Кавказе начал свою службу, но карьера его в основном связана с европейским театром военных действий $[8$, с.29-31;9].

Список полководцев, которых можно уподобить «местночтимым святым», в хронологической последовательности открывают П.Д. Цицианов (1754-1806) и П.С. Котляревский (1782-1851). Котляревского даже называли «кавказским Суворовым» [10]. Самым знаменитым полководцем Кавказской войны является А.П. Ермолов (1777-1861). А.С. Пушкин упомянул этих троих военачальников в эпилоге поэмы «Кавказский пленник», где излагалась схема «покорения» этого края. И.Ф. Паскевич и Н.Н. Муравьев получили почетные «победные» приставки к своим фамилиям. Первый стал графом Эриванским в честь взятия персидской крепости Эривань и победы в войне 1826-1828 гг., а второй - в честь взятия крепости Карс в декабре 1855 г. Очень популярным и известным был казачий генерал Н.П. Слепцов. В 1846 году солдаты даже сложили о нем песню [11, с.121]. Его именем назвали станицу на реке Сунже и присвоили почетное имя одному из казачьих полков. На центральной площади станицы поставлен памятник этому храброму и популярному командиру [12]. На Кавказе было поставлено еще несколько памятников «своим» героям, причем все они были сооружены по инициативе чинов Кавказского корпуса и на собранные ими средства [13, с.196-199].

Другой полководец, уроженец Лифляндии Р.К. Фрейтаг, имел репутацию «спасителя», поскольку несколько раз приходил на помощь войскам, оказавшимся в безвыходном положении. В 1845 г. именно его своевременное появление спасло корпус М.С. Воронцова от полного уничтожения в ходе трагической Даргинской экспедиции. О его популярности среди нижних чинов свидетельствуют слова солдатской песни: «С нами Бог и Фрейтаг с нами...» [14]. Легендарной фигурой в Кавказском корпусе был генерал Н.И. Евдокимов, родившийся в семье простого солдата на Тереке в станице Наурской. Он прошел боевой путь от рядового до генерала-отинфантерии, имел тяжелые ранения, получил титул графа за свои заслуги.

В кавказском корпусе были свои солдаты-герои. Рядовой Эриванского полка Гаврила Сидоров погиб во время русско-персидской войны 1804-1813 гг. По преданиям он предложил соорудить «живой мост» для того, чтобы перевезти пушку через глубокую канаву. Колесо одного орудия соскочило с камня и ударило его в висок. Второй - солдат Тенгинского полка Архип Осипов взорвал пороховой погреб укрепления Михайловское в 1842 г., когда горцам удалось в него ворваться. Рассказы об этих подвигах запечатлены в картинах, лубках, на памятнике чинам Эриванского полка и почти во всех полковых историях частей Кавказского корпуса [15, с.134-137].

На Кавказе десятилетиями войска жили в атмосфере перманентных боевых действий, что способствовало значительным сдвигам в формировании представлений о складывании их в некую общность. Эта мысль в разных вариантах присутствует во многих историях кавказских полков. «...Кавказская война не есть война обыкновенная; Кавказское войско не есть войско, делающее кампанию. Это скорее воинственный народ, создаваемый Россией и противопоставляемый воинственным народам Кавказа для защиты России...», - писал участник войны князь Д. Святополк-Мирский [16, с.59].

Книга Д.Ф. Шабанова «История 13-го лейбгренадерского Эриванского полка в трех частях», изданная в Тифлисе в трех частях в 1871 г. стала первой «кавказской» полковой историей. Через четыре года появилась версия истории части для нижних чинов [17]. В 1907 г. была издана еще одна краткая история этой части [18]. Эриванский полк был сформирован на основе егерского генерал-майора Лазарева полка, который в 1799 пришел в Тифлис и стал на тот момент главной опорой России в Закавказье. Эта часть первая и единственная получила почетное «кавказское» наименование за взятие крепости Эривань, имевшей огромное стратегическое и символическое значение. Названия других полков Кавказского корпуса не были напрямую связаны с победами, являлись данью традиции называть воинские части по «местностям». Однако все они придавали полкам дополнительный местный колорит (Кабардинский, Куринский, Апшеронский, Грузинский, Бакинский и т.д.).

Полки, отличившиеся при покорении Кавказа, очень ревниво относились к правам на символическое наследие. В 1881 г. вышел труд А.Л. Зиссермана «История 80-го пехотного Кабардинского генерал-фельдмаршала князя Барятинского полка. (1726-1880)», состоявший из трех томов, и отпечатанный в Санкт-Петербурге. Ответом еще одной постоянно соперничавшей с ними воинской части был выход сочинения полковника Г.Н. Казбека «Куринцы в Чечне и Дагестане. 1834-1861 гг.», опубликованного в Тифлисе в 1885 г. Затем в своеобразное соревнование включились другие части Кавказского корпуса. В 1892 г. появился роскошно напечатанный трехтомник Л.А. Богуславского «История Апшеронского полка. 17001892 г», дополненный специальной брошюрой для нижних чинов [19]. Реакция давних конкурентов в боевой славе на такие вызовы не заставила себя долго ждать: в 1902 г. из печати вышло богато украшенное юбилейное 
издание о походах и сражениях куринцев [20]. Трудно сомневаться в том, что появление указанных историй повлияло на подготовку новых летописей Эриванского гренадерского полка сначала в «упрощенной» форме, а затем в виде пятитомника, украшенного рисунками известного художника-баталиста Н.С. Самокиша [21]. Эта практика двух вариантов - для «образованной публики» и для нижних чинов проявилась и в подготовке истории Тенгинского полка [22]. В десятилетие перед Перовой Мировой войной список полковых «кавказских» историй пополнился еще десятком изданий.

Историографы кавказских войск объясняли причину войны с горцами так же, как это делали профессиональные историки. «...России судьбой было предназначено стать властительницей этого края и положить предел тем смутам и повсеместной взаимной вражде, расшатанности всех государственных и общественных связей, которые довели богатый, цветущий, наделенный природой всеми благами Кавказ на край бездны», - так объяснил значение побед Кабардинского полка автор истории этой части А.Л. Зиссерман [23, с.260].

Войска Кавказского корпуса встретили противников, которых не знали полки, сражавшиеся в Европе. Персидская и турецкая армия имели в своем составе много иррегулярных формирований, не знакомых с дисциплиной и не ведавших о «европейских» принципах обращения с пленными, ранеными и с мирным населением. В ответ на все это русские солдаты и офицеры не считали себя обязанными «церемониться» с неприятелем. Горцы вообще считались разбойниками и бутовщиками, со всеми вытекающими из этого последствиями.

Важным элементом корпоративного мировоззрения являются представления о «чужом»: о соперниках и врагах. В полковых историях полков русской армии среди таковых значатся поляки [24, с.11-17; 25, с.54-55]. Кавказ был местом, куда в 1813 г. отправили более двух тысяч уроженцев бывшей Речи Посполитой, которые воевали в армии Наполеона Бонапарта и были взятых в плен с оружием в руках. Не будучи уверенными в их надежности, командование распределило их в основном по гарнизонам крепостей и казачьим станицам. Впоследствии на Кавказ сослали большое число участников восстания 1830-1831 гг. и разного рода «неблагонадежных». «Поляки переходили на сторону противника в основном по идейным соображениям: это был их вклад в борьбу за свободу порабощенной отчизны. Они добровольно участвовали в боевых операциях, обучали горцев стрельбе из пушек и сами служили канонирами» [26, с.113].

В рапорте от 7 апреля 1840 года генерала П.Х. Граббе военному министру А.И. Чернышеву говорилось: «... По словам лазутчиков, эти дезертиры (поляки - П.Ч.) доставили горцам первое сведение о бедственном положении форта Лазарева и подали первую мысль о на- падении на оный, принимая на себя и исполнение этого предприятия. Они-то изобрели новый род оружия длинный шест, к одному концу которого прикрепляется коса, чтобы колоть и рубить, а к другому крючья, чтобы влезать на крепостные верки. Ныне это оружие находится у горцев в значительном количестве. Они производят съемку атакуемых мест, подают нужные советы для организации сборищ, а при штурме идут всегда в голове колонны. Между ними особенно отличается своей предприимчивостью унтер-офицер одного из Черноморских линейных батальонов, служивший капитаном артиллерии в польской армии во время мятежа 1831 года» [27, c.252].

Примечательно, что в историях кавказских полков этот сюжет (измена поляков) не получил такого распространения как в официальной истории военных действий против турок, персов и горцев. Упоминания о поляках, нарушивших присягу, буквально единичны и не содержат конкретных данных (имя, место, обстоятельства), что позволяет предположить, что мы имеем дело с «внешним заимствованием», неким обязательным элементом, в атмосфере полонофобии второй половины XIX- начала XX BB.

В полковых историях довольно часто демонстрировалась «приватизация» Кавказской войны, когда ведение боевых действий становилось не выполнением присяги, а личной инициативой военнослужащих. «Иные из начальников пользовались малейшим удобным случаем для набегов просто от скуки, из желания покипятить кровь под гул выстрелов и крики чеченцев; многие делали это ради выслуги перед начальством ради случая прислать реляцию и показать свои полководческие способности...» [23, с.11]. В этих повествованиях продолжительная изоляция батальонных, ротных и даже взводных командиров от вышестоящих начальников на Кавказе переносила точки принятия военно-политических решений на капитанов и поручиков [28, с.254-255].

В полковых сказаниях всячески подчеркивалось, что полки, воевавшие в Чечне и Дагестане, самим своим видом резко отличались от частей, расквартированных в прочих районах империи. «...Кавказские офицеры, и солдаты были одеты крайне своеобразно. Всякого свежего человека, первый раз встречавшего кавказские войска, поражало это полное отсутствие воинского вида, и именно в то время, когда высшие сферы признавали форму за сущность и малейшее отступление от образцов готовы были считать падением доблести... В общем, неказисты были с внешней стороны кавказцы, не любили они также парадов, смотры их были обыкновенно неудачны, но это не мешало им оказывать чудеса храбрости и выносливости» [28, с.128-129].

В хрониках частей большое внимание уделено такой особенности боевых действий в этой части империи как 
санитарные потери, которые там многократно превышали боевые. Лейб-гвардии Сводный полк в 1826-1828 гг. потерял одного человека убитым, и 319 - умершими от болезней [29, с.77]. Эта мрачная статистика должна была компенсировать недостаточную «кровопролитность» войны с горцами, поскольку традиционно боевые заслуги измерялись в том числе и потерями, а убитых и раненых в мелких, но постоянных стычках с горцами, было не такое количество, как в сражениях на европейских театрах военных действий [30, с.151].

Авторы полковых историй формировали представление о том, что многие аулы в Дагестане, несмотря на то, что их строили не европейские военные инженеры, представляли собой мощные фортификационные сооружения. Эти селения, официально не называвшиеся крепостями, вынуждали применять все тактические приемы и технические средства (бомбардировка, устройство подкопов, установление блокады). В 1846 г. на аул Гергебиль обрушили более тысячи бомб и ядер, но горцы отказались сдаваться [31, с.173].

Авторы старались обратить внимание читателей, что достижение побед над сильным противником происходило в «невыгодных» для кавказских полков условиях, одним из которых было пополнение частей, расположенных на этой имперской окраине, теми рекрутами и солдатами, от которых старались избавиться полки в европейской части России. На Кавказ отправляли пойманных дезертиров, сектантов, разные категории «штрафованных», отличившихся «порочным поведением» [30, с.111-112]. В 1837 г. Тенгинский полк более чем наполовину состоял из «ненадежных» солдат [28, с.169].

Поскольку сражение на реке Валерик по местным масштабам было одним из самых значительных за всю историю Кавказской войны, в полковых историях ему, как Бородинской битве в историях «европейских полков» придается особое значение [28, с.272-276].

Образ горца авторы полковых историй рисовали не по литературным штампам, созданными усилиями таких писателей как А.А. Бестужев-Марлинский и другими, а гораздо мене известными авторами. Они заостряли внимание на такой черте как коварство. Историограф Апшеронского полка подробно описал, как жители села
Цатаных в Дагестане обещали помощь размещенной там роте, но когда пришел Шамиль, ударили своим защитникам в спину. В результате солдатам пришлось выйти из аула и обороняться в недостроенном укреплении [32, с.71]. Особенность боевых действий в горах против врага, который не воевал на европейский манер, вели к тому, что русские для повышения эффективности приспосабливались к местным условиям. «Наш солдат... сообразив характер кавказской войны, усвоил себе манеру горца и часто поражал его добытым опытом, его же собственным оружием и в нравственном, и в буквальном отношении...», писал один из мемуаристов [33, с.53].

В полковых историях полков, служивших на этой имперской окраине, довольно часто акцентируется внимание на хозяйственной автономии отдельных частей, которая была часто залогом сохранения боеспособности в условиях фактического отсутствия налаженной интендантской системы [28, с.41].

Таким образом, многолетняя обособленность войск, воевавших на Кавказе, специфика боевых действий с горцами, турками и персами, формирование регионального списка героев и «мест памяти», собственные традиции и предания способствовали превращению полков в сообщество, имевшее много признаков отдельной корпорации. В историях этих частей отражена вся вышеперечисленная специфика боевых действий на этой имперской окраине и их идентичность.

Авторы полковых историй всем способами соединяли историю своих частей с судьбами тех, кто значился в списке «выдающихся российских военачальников»Петр Великий, Суворов, Кутузов, Румянцев, Багратион, Ермолов, Скобелев, которых можно уподобить всероссийским святым. Кавказ же породил «список славы», который можно сравнить с местночтимыми святыми.

Для полков, для которых главным делом было «покорение Кавказа», история походов в Чечне и Дагестане, сражений с турками и персами, при всем общем уважении к таким общеимперским символам славы как Полтава, Бородино, Севастополь и Плевна, особое значение имело те, что напоминали об их особых корпоративных заслугах (Эривань, Дарго, Валерик, Ахалцых, Карс, Гуниб и т.д.).

\section{ЛИТЕРАТУРА}

1. Газетти А.Л. Хроника Кавказских войск. Тифлис: Тип. Канцелярии Главноначальствующего гражданской частью на Кавказе, 1896. 598 с.

2. Лапин В.В. Хронологические рамки Кавказской войны в контексте ее историографии // Вестник Санкт-Петербургского университета. 2007. Серия 2. История. Вып.3.С.78-89

3. Ковалевский П.И. Восстание в Чечне и Дагестане в 1877 и 1878 гг. / проф. П.И. Ковалевский. - СПб.: Тип. М. И. Акинфиева, 1912. 95 с., [1] л. карт.: ил., карт., портр.

4. Биография генерала Котляровского/ Соч. гр. В. Соллогуба. - Тифлис: тип. Канцелярии наместника кавказского, 1854. 220 с., 1 л. фронт. (портр.). 
5. Кишмишев С.0. Война в турецкой Армении. 1877-1878 гг. СПб.: Изд. Военная типография, 1884.536 с.

6. Евдокимов-Добровольский Н.И. Экспедиция в Салаватию в 1858 году // Кавказский сборник. Т. 4. Тифлис. 1876 г. 444 с.

7. Зиссерман А.Л. Фельдмаршал князь Александр Иванович Барятинский. 1815-1879/ [Соч.] А.Л. Зиссермана. Т. 1-3. - Москва: Унив. тип., 1888-1891. Т. 1. 1888. - XVI, 392, XVII-XX с., 1 л. портр.

8. Анисимов Е.В. Генерал Багратион. Жизнь и война. М.: Молодая гвардия, 2009. - 822 с.: ил.

9. Соловьёв В.А. Суворов на Кубани, 1778-1793. Краснодар: Кн. изд-во, 1986. 188,[2] с.: ил.

10. Соханская Е.А. Биографический очерк генерала от инфантерии Котляревского. СПб.: тип. Майкова, ценз.1870. 32 с.

11. Галушко Ю.А. Казачьи войска России: Крат. ист.-хронол. справ. казачьих войск до 1914 г. М.: Информ.-изд. агентство "Рус. мир", 1993. 231 с., [2] л. схем: ил.

12. Н.П. Слепцов, покоритель Чечни и Дагестана, 12-го выпуска из Николаевского кавалерийского училища 1836 г. Петроград: Ком. Ист. музея Николаев. кавалерийского уч-ща, ценз. 1916. 132 с., 3 л. факс., портр. : ил.

13. Сокол К.Г. Монументальные памятники Российской империи. Каталог М.: Вагриус Плюс, 2006. 429 с., [2] с.: ил.

14. Беклемишев Н.П. Поход графа Воронцова в Дарго и «Сухарная экспедиция» в 1845 г. (из записок участника) // Даргинская трагедия. 1845 год. СПб.: Изд. журнала «Звезда», 2001. С. 534-551.

15. Памятники времен утверждения русского владычества на Кавказе / Под ред. ген.-майора Потто. Вып. 1. - Тифлис: Воен.-ист. отд. при Штабе Кавк. воен. окр., 1906. 244 c.

16. Акты, собранные кавказской археографической комиссией: Т. 1-12 / Арх. Гл. упр. наместника кавк. Т. 11. - Тифлис: тип. Гл. упр. Наместника Кавк., 1888. $1035 \mathrm{c}$.

17. Шабанов Д.Ф. Краткая историческая записка о службе 13-го лейб-гренадерского Эриванского Его Императорского Величества полка. Тифлис: тип. Окр. Штаб Кавк. Воен. округа. 1875.89 с.

18. Шервашидзе М.Л. Краткая история 13 лейб-гренадерского Эриванского Его Величества полка: Слово, сказ. Учеб. команде этого Полка нач. ее штабс-кап. кн. М. Шервашидзе. - Тифлис: тип. Канц. наместника е. и. в. на Кавказе, 1907. 26 с., 1 л. портр.

19. Богуславский Л.А. Апшеронская памятка. 1700-1894: Крат. история Апшерон. полка для солдат / Сост. того же полка кап. Л.А. Богуславский; С прил. 2 портр. и 157 рис. в тексте акад. Н. Самокиша. - СПб.: тип. А. Бенке, 1894. - [8], 540 с., 1 л. фронт. (грав. тит. л.), 2 л. портр.: ил.

20. Брюховецкий Г.А. 100 лет боевой и мирной жизни 79-го Пехотного Куринского полка, 1802-1902 гг. : Крат. очерки из истории полка для ниж. чинов / Сост. штабс-кап. Брюховецкий. - СПб.: типо-лит. С.Н. Цепова, 1902. 198 с., 1 л. карт. : ил.

21. Андреев А.П. Подарок солдату к 250-й годовщине 13-го Лейб-гренадерского Эриванского его величества полка (б. Бутырский полк). 1642-1892 / Сост. того же полка поручик А.П. Андреев. - СПб.: А.Н. Хвостов, 1892. - 64 с., 1 л. ил.; Бобровский П.0. История 13-го Лейб-Гренадерского Эриванского Его Величества полка за 250 лет. Ч.3. СПб.: Тип. В.С. Балашева, 1892-1898. 771 с.

22. Лавров А.Н. Краткое описание боевой жизни и деятельности 77-го Пехотного Тенгинского его императорского высочества великого князя Алексея Александровича полка. 1700-1900: Сост. для нижних чинов А.Н. Лавров по материалам, собр. того же полка поручиками Раковичем и Тышецким, а также самим авт. - Тифлис: тип. Канц. главнонач. гражд. ч. на Кавказе, 1900. - [6], 150 с.; Ракович Д.В. Тенгинский полк на Кавказе. 1819-1846. Правый фланг. Персия. Черноморская береговая линия: юбилейн. вып. / сост. Ракович; под ред. Потто. - Тифлис: Воен.-ист. отд. при Штабе Кавказ. воен. окр., 1900. XX, 396, 80 с., [18] ил., карт., портр. : табл.

23. Зиссерман А.Л. История 80-го Пехотного Кабардинского генерал-фельдмаршала князя Барятинского полка. (1726-1880) 3 т. / Сост. А. Зиссерман. Т. 1. СПб.: тип. В. Грацианского, 1881.

24. Абаза К.В. Краткая история 7-го Гренадерского самогитского генерал-адъютанта графа Тотлебена полка. 1788-1817-1833-1888: сост. для нижних чинов по распоряжению командира Гренадерского корпуса генерала от артиллерии Столыпина поручиком сего полка К.В. Абаза. - М.: тип. Т-ва И.Н. Кушнерев и К, 1888 (обл. 1889). - 100 с., 12 л. ил., карт.

25. Козлов Д.Ф. Краткая боевая история 117-го Пехотного Ярославского полка. 1763-1913 / Кап. Д.Ф. Козлов. - Рогачев: тип. насл. Залкинда, [1913]. - 90 с., 5 л. ил.: ил., портр.

26. Лапин В.В. Армия России в Кавказской войне XVIII-XIX вв. СПб. 2008. 396 с.

27. Акты, собранные кавказской археографической комиссией: Т. 1-12 / Арх. Гл. упр. наместника кавк. Т. 9. - Тифлис: тип. Гл. упр. Наместника Кавк., 1866-1904. 979 C.

28. Ракович Д.В. Тенгинский полк на Кавказе. 1819-1846. Правый фланг. Персия. Черноморская береговая линия: юбилейн. вып. / сост. Ракович; под ред. Потто. - Тифлис: Воен.-ист. отд. при Штабе Кавказ. воен. окр., 1900. - XX, 396, 80 с., [18] ил., карт., портр.: табл.

29. Скрутовский С.Э. Лейб-гвардии сводный полк на Кавказе в Персидскую войну с 1826 по 1828 год: Эпизод из истории Л.-гв. гренад. полка: По источникам сост. С.Э. Скрутковский, поручик Л.-гВ. гренад. полка. - СПб.: типо-лит. В.А. Вацлика, 1896. - 89 с., 1 л. фронт. (портр.), 4 л. пл., карт.

30. Бобровский П.0. История 13-го Лейб-Гренадерского Эриванского Его Величества полка за 250 лет. Ч.З. СПб.: Тип. В.С. Балашева, 1892-1898. 771 с.

31. Богуславский Л.А. История Апшеронского полка. 1700-1892: Т. 1 - 3 / Сост. Л. Богуславский, штабс-кап. 81 пех. Апшер. полка; Вел. кн. Георгий Михайлович. - СПб.: Тип. М-ва Путей Сообения (А. Бенке), 1892. 586 с.

32. Богуславский Л.А. История Апшеронского полка. 1700-1892: Т. 1 - 3 / Сост. Л. Богуславский, штабс-кап. 81 пех. Апшер. полка; Вел. кн. Георгий Михайлович. - СПб.: Тип. М-ва Путей Сообщения (А. Бенке), 1892.566 с.

33. Кавказский сборник, издаваемый в бытность е. и. в. Великого князя Михаила Николаевича главнокомандующим Кавказскою армией [Текст]. Т. 4. Тифлис: [б. и.], 1876-1912.

(c) Чернов Павел Вячеславович (pulsar.pvl@mail.ru).

Журнал «Современная наука: актуальные проблемы теории и практики» 